\title{
"Bankers and financial advisers in an emerging economy: are they financially
}

literate?"

\begin{tabular}{|c|c|}
\hline \multirow{3}{*}{ AUTHORS } & \multirow{2}{*}{$\begin{array}{l}\text { Alicia Lethepa (D https://orcid.org/0000-0002-3650-6711 } \\
\text { Reon Matemane (D) http://orcid.org/0000-0003-0225-3928 }\end{array}$} \\
\hline & \\
\hline & Nyasha Dhlembeu (D https://orcid.org/0000-0002-6088-1845 \\
\hline ARTICLE INFO & $\begin{array}{l}\text { Alicia Lethepa, Reon Matemane and Nyasha Dhlembeu (2020). Bankers and } \\
\text { financial advisers in an emerging economy: are they financially literate?. Banks } \\
\text { and Bank Systems, 15(2), 16-27. doi:10.21511/bbs.15(2).2020.02 }\end{array}$ \\
\hline DOI & http://dx.doi.org/10.21511/bbs.15(2).2020.02 \\
\hline RELEASED ON & Monday, 13 April 2020 \\
\hline RECEIVED ON & Friday, 14 February 2020 \\
\hline \multirow[t]{2}{*}{ ACCEPTED ON } & Monday, 30 March 2020 \\
\hline & $(\mathrm{cc}) \mathbf{E Y}$ \\
\hline LICENSE & $\begin{array}{l}\text { This work is licensed under a Creative Commons Attribution } 4.0 \text { International } \\
\text { License }\end{array}$ \\
\hline JOURNAL & "Banks and Bank Systems" \\
\hline ISSN PRINT & $1816-7403$ \\
\hline ISSN ONLINE & $1991-7074$ \\
\hline PUBLISHER & LLC "Consulting Publishing Company "Business Perspectives" \\
\hline FOUNDER & LLC "Consulting Publishing Company "Business Perspectives" \\
\hline
\end{tabular}

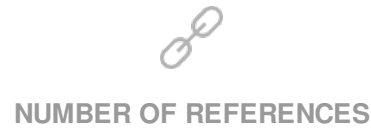

48

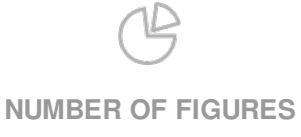

0
韸

NUMBER OF TABLES

3

C The author(s) 2023. This publication is an open access article. 


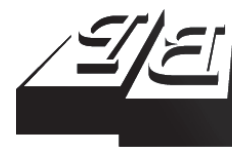

\section{BUSINESS PERSPECTIVES}

LLC "CPC "Business Perspectives" Hryhorii Skovoroda lane, 10, Sumy, 40022, Ukraine www.businessperspectives.org

Received on: $14^{\text {th }}$ of February, 2020 Accepted on: $30^{\text {th }}$ of March, 2020 Published on: $13^{\text {th }}$ of April, 2020

C Alicia Lethepa, Reon Matemane, Nyasha Dhlembeu, 2020

Alicia Lethepa, MCom Financial Management, Student, Faculty of Economic and Management Sciences, Department of Financial Management, University of Pretoria, South Africa.

Reon Matemane, Master in Financial Management, Senior Lecturer, Faculty of Economic and Management Sciences, Department of Financial Management, University of Pretoria, South Africa. (Corresponding author)

Nyasha Dhlembeu, MCom Financial Management, Project Coordinator, Faculty of Economic and Management Sciences, Department of Accounting, University of Pretoria, South Africa.
This is an Open Access article, distributed under the terms of the Creative Commons Attribution 4.0 International license, which permits unrestricted re-use, distribution, and reproduction in any medium, provided the original work is properly cited.

Conflict of interest statement: Author(s) reported no conflict of interest
Alicia Lethepa (South Africa), Reon Matemane (South Africa), Nyasha Dhlembeu (South Africa)

\section{BANKERS AND FINANCIAL ADVISERS IN AN EMERGING ECONOMY: ARE THEY FINANCIALLY LITERATE?}

\begin{abstract}
Financial literacy is important for employees in the banking sector, as they are required to advise and administer the savings and investments of their clients. This study aims to establish financial literacy levels for banking employees and socio-demographic variables that influence their financial literacy levels. When collecting the necessary data for analysis, a survey was used for the total final sample of 120 employees of the banking sector. Descriptive statistics, the two-sample T-test and a simple ANOVA were used to determine the actual financial literacy levels and the socio-demographic factors influencing them. Overall, the employees were found to have moderately high levels of financial literacy. Only gender, race and education level were found to have an influence on financial literacy levels. This study informs the banking sector about how well employees are involved in financial literacy and which socio-demographic groups of their employees they need to focus on when exploring financial education programs.
\end{abstract}

Keywords banking, bankers, emerging economy, financial advisers and financial literacy

\section{JEL Classification G21, I25}

\section{INTRODUCTION}

Financial literacy has increasingly become an important phenomenon for authorities, scholars and various institutions, not only in South Africa but globally (Jana, Sinha, \& Gupta, 2019; Hussain \& Sajjad, 2016; Refera, Dhaliwal, \& Kaur, 2015). This concept has received immense attention, as the financial landscape and markets are growing and becoming more complex by the day (Lusardi \& Mitchell, 2014; Lachance, 2014). Over the past twenty years, the banking sector has introduced a variety of financial products and created access to global products. Furthermore, there has been a shift to defined contribution pensions when people are responsible for their own retirement planning (Klapper \& Lusardi, 2019; Xue, Gepp, O’Neill, Stern, \& Vanstone, 2019). As a result, people now have a personal responsibility to make the right financial decisions and have healthy financial wellbeing.

Generally, there is a consensus among researchers that being financially literate can help in financial decision-making processes such as retirement planning (Boisclair, Lusardi, \& Michaud, 2017; Brown \& Graf, 2013, Lusardi \& Mitchell, 2011), household savings and debt levels (Hussain \& Sajjad, 2016; De Bassa Scheresberg, 2013) and choosing investment products (Van Rooij, Lusardi, \& Alessie, 2011a). Besides, financial decision-making capabilities are enhanced when a person is financially literate. Enhanced financial decision-making capabilities are critical for banking employees who usually provide financial advice to the ordinary people. This view is supported by Mundy and 
Masok (2011) who posit that financial literacy is not only desirable but also favorable for providers of financial services and the overall financial system in its entirety.

Stimulating savings and investments is the primary role of the banking sector (Seth, 2014). This sector is particularly important in the South African economy because it is the sector that provides core financial assistance and functions such as transacting, deposit taking, lending and indemnity to South African consumers (Chetty, 2011). The studies conducted in South Africa did not only find financial literacy levels to be low amongst the university students, college students (Oseifuah \& Gyekye, 2014) and the educated (Shambare \& Rugimbana, 2012) but even among those who already possess both tertiary education and the actual working experience (Matemane, 2018).

The aforesaid South African studies and those conducted elsewhere in the world, such as Lusardi and Mitchell (2011), Klapper and Lusardi (2019) and many others, focused on financial literacy levels of ordinary individuals only. They have neglected the crucial part of the society, namely, banking employees who are responsible for actually giving financial advice. Therefore, the knowledge of financial literacy levels for banking employees is limited in both developed and developing economies. According to Nguyen and Rozsa (2019), those who are financially illiterate seek advice from banking employees, and this advice substitutes financial literacy in making financial decisions. In view of the crucial role they play in society, not knowing the nuances and the levels of banking employee's financial literacy can be detrimental not only to the banking sector but also to the overall economy of a country. The contribution that this study is making to the financial literacy debate lies in its attempt to elucidate the levels and nuances of financial literacy among banking employees in an emerging economy setting.

The finance and business services industry, including the banking sector, provides about $19 \%$ of South Africa's gross domestic product (GDP) (Stats SA, 2019). To stay ahead of rivalry and competition, banks should inculcate the customer centric mentality whereby customers receive good quality services. According to Onyango (2014), this would require banks to recruit, train, develop and retain qualified employees. Given that the banking sector provides core financial services to South African consumers, it becomes paramount that their financial literacy levels are sound for them to give financial advices and effectively manage the funds entrusted by their clients. Therefore, banking remains a critical sector of the economy (Erasmus, 2014).

This study, therefore, aims to assess the levels of financial literacy among the South African banking employees and to establish the socio-demographic variables influencing such levels of financial literacy. In the passage that follows, the literature underpinning the study is discussed resulting in the development of hypotheses. Thereafter, the research methodology that guides the study is discussed, followed by the results. The last section gives conclusions and recommendations for future studies.

\section{LITERATURE REVIEW AND HYPOTHESES DEVELOPMENT}

\subsection{The concept of financial literacy and how it is measured}

Although the concept of financial literacy dates back to the 1900s, limited research had been conducted prior to 2008. Furthermore, no study has provided a standardized definition of the concept
(Botha, 2014). A number of studies contain existing conceptual definitions of financial literacy (Xu \& Zia, 2012; Atkinson \& Messy, 2011; Huston, 2010). These definitions do not contradict each other but in fact they all encompass the idea of having the skill to make good financial decisions. This study adopts Lusardi's $(2008$, p. 2) definition: "Knowledge of basic financial concepts, such as working of interest compounding, the difference between nominal and real values, and the basics of risk diversification". This definition also helps measure financial literacy appropriately. 
Financial literacy has not always been referred to as 'financial literacy', and over the years different phrases and terms have been used. These terms include financial knowledge, financial capability, financial culture and financial insight (Louw, Fouché, \& Oberholzer, 2013; Bucher-Koenen \& Lusardi, 2011; Huston, 2010). The terms are used interchangeably.

As there are various ways to define financial literacy, so are the ways to measure financial literacy (Hung, Parker, \& Yoong, 2009). However, literature has highlighted two main approaches to measuring financial literacy: 1) the Organization for Economic Co-operation and Development (OECD)'s approach (OECD INFE, 2011), and 2) the approach introduced by Lusardi, hereafter referred to as the Lusardi approach (Snyman, 2014).

The OECD approach subdivides financial literacy into four dimensions:

1) financial control;

2) financial planning;

3) choosing financial products; and

4) knowledge and understanding (Roberts, Struwig, \& Gordon, 2014).

Financial control (day-to-day money management) pertains to whether individuals create budgets, adhere to them, save frequently and whether they retain records of their expenses. Financial planning refers to information that determines the extent to which consumers make provision for emergencies and the savings or insurance they have. This includes the individual's financial support for retirement and anticipated expenses such as education and health care.

Choosing financial products focuses on the consumers' capability to select suitable services and products, how they select the products and whether they compare different offerings from competitors. Last, financial knowledge and understanding provides information on the level to which consumers keep abreast of developments in financial services industry, and whether core concepts are understood by consumers and their knowledge of financial products offering and services.
Meanwhile, the Lusardi approach is a survey, which measures "basic financial literacy" and tests for proficiency in calculating interest rates, effects on inflation and risk diversification. This set of questions is commonly used across the world in measuring financial literacy (Lusardi \& Mitchell, 2009; Shambare \& Rugimbana, 2012; Boisclair, Lusardi, \& Michaud, 2017). Lusardi and Mitchell further developed an additional survey that measured the understanding of investments. The quizzes thereof are used to measure "advanced financial literacy".

\subsection{The relevance of financial literacy}

Recently, there has been a substantial escalation in the quantity and complexity of financial products and services (Dudchyk, Matvijchuk, Kovinia, Salnykova, \& Tubolets, 2019; Murendo \& Mutsonziwa, 2017). The escalation in these financial products has brought both opportunities and challenges for people (Xue, Gepp, O'Neill, Stern, \& Vanstone, 2019). These financial products and services allow consumers to access a variety of products and services. However, comprehension of the innovated financial product offerings and services is imperative. This is because better understanding of financial markets gives consumers the opportunity to participate in the financial ecosystem and make more informed financial decisions (Nguyen \& Rozsa, 2019; Dudchyk et al., 2019; Sallie, 2015).

The financial literacy levels of individuals have a positive impact on their debt management (Xu \& Zia, 2012), investment in stock markets (Van Rooij, Lusardi, \& Alessie, 2011b), household savings (Babiarz \& Rob, 2014; Murendo \& Mutsonziwa, 2017), retirement planning (Lusardi \& Mitchell, 2011; Brown \& Graf, 2013; Botha 2014; Boisclair, Lusardi, \& Michaud, 2017) and entrepreneurship skills (Oseifuah, 2010). Therefore, financial literacy is a key survival tool in ensuring financial security. Besides, research has shown that business performance is enhanced when business owners have higher financial literacy levels (Ngek, 2016).

Literature has shown that there are various socio-demographic variables that affect financial literacy. They are discussed in the following section, with a focus on age, gender, race, marital status and education level. 


\subsection{Socio-demographic factors affecting financial literacy}

\subsubsection{Gender}

Researchers in the past have shown that gender plays an important role in explaining financial literacy differences. Most studies have revealed that males are more knowledgeable in financial matters than females (Almenberg \& Säve-Söderbergh, 2011; Chen \& Volpe, 2002, Brown \& Graf, 2013; Shambare \& Rugimbana, 2012; Boisclair, Lusardi, \& Michaud, 2017).

Although there is general consensus among scholars that financial literacy of males is higher than that of females, some studies have yet not identified differences in the financial literacy levels between the two genders. In their study, BucherKoenen and Lusardi (2011) found no statistically significant differences in financial literacy levels between males and females. In addition, according to Botha (2014) and Sallie (2015), gender had no influence on financial literacy.

\subsubsection{Age}

Existing literature gives mixed results as to whether age is related to financial literacy. Almenberg and Säve-Söderbergh (2011) found lower financial literacy levels among the youth in Swedish population. In support of this, Lusardi and Mitchell (2011) also found financial literacy to be the lowest among those who are younger than 35 years in New Zealand, Italy, USA, Japan, Germany, Sweden and Netherlands.

Chen and Volpe (2002), however, asserted that one cannot be financially literate only because of old age. As people have had more financial exposure, their financial skills are enhanced as they learn through experience. Meanwhile, Oseifuah and Gyekye (2014) and Sallie (2016) found that age does not significantly affect financial literacy.

\subsubsection{Race}

Whilst most studies in financial literacy do not comment on the racial or ethnic differences, great disparities in financial knowledge have been found in the USA among different racial and ethnic groups. White people and Asian people are more likely to possess higher levels of financial literacy compared to African Americans and Hispanics (Lusardi \& Mitchell, 2011). In the South African context, it was found that several disparities existed in the levels of financial literacy between Indians or Whites compared to Coloreds or Blacks. Matemane (2018) and Roberts, Struwig, and Gordon (2012) found that the Indians and White have very high overall financial literacy scores, while Black African and Colored groups had very low financial literacy scores in the South African context.

\subsubsection{Marital status}

Some studies revealed that financial literacy was positively related to marital status (Bashir, Arshad, Nazir, \& Afzal, 2013). Taylor and Wagland (2011) revealed that single people had lower financial literacy levels than married people. Other studies found that marital status reduced the financial literacy gap between males and females by $25 \%$ (Fonseca, Mullen, Zamarro, \& Zissimopoulos, 2012). Given the above, all the studies echo similar results.

\subsubsection{Education}

Evidence proves that financial education can cause an improvement in both financial literacy and the quality of financial decisions. According to Xu and Zia (2012), the higher level of education would result in higher financial literacy levels. However, Shambare and Rugimbana (2012) studied financial literacy levels of the university students at a South African university and found that the students were not financially literate. The field of study or the nature of the degree studied also affect the level of financial literacy. For example, Matemane (2018) found that people with a tertiary qualification in non-commercial streams were not as financially literate as those with a tertiary qualification in commerce. Therefore, a need exists, even among the educated, to strengthen their basic financial skills.

\subsection{Hypotheses development}

Given the above literature review, which forms part of theoretical and conceptual foundations of 
the study, the following hypotheses are developed:

H1: The average financial literacy scores of male employees in the banking sector are significantly different from those of their female counterparts.

H2: The average financial literacy scores of older employees in the banking sector are significantly different from those of their younger counterparts.

H3: The average financial literacy scores vary significantly among different racial groups in the banking sector.

H4: There is a difference in the average financial literacy scores of the banking sector employees with different marital status.

H5: The average financial literacy scores vary significantly among the banking sector employees possessing different educational qualifications.

It is expected that as the employees in the banking sector interact with clients and are concerned with the various financial product offerings, the financial knowledge of these individuals is enhanced. Therefore, the following hypotheses are put forward:

H6: The average financial literacy scores vary significantly among banking employees occupying different office positions.

H7: The average financial literacy scores vary significantly among banking employees with different banking experience.

The following section discusses the methodology used to achieve the objectives of the study and test the above hypotheses.

\section{METHODOLOGY}

This study is quantitative in nature, and the approach is in line with many similar studies discussed in literature review. To achieve the study objectives, a survey was adopted in which a self-administered questionnaire was used and distributed through an electronic survey instrument. The mode of dissemination included email and social media (Facebook and WhatsApp) invitations. This study adopted the Lusardi approach to measure financial literacy levels. "Basic and advanced" financial literacy questions were used. The questionnaire, however, was tailor-made for the South African context by changing the currency to the South African Rand and amending terms such as mutual fund to unit trust. (The corresponding author would make the questionnaire available upon request).

As the questionnaire has been used in similar financial literacy studies (Lusardi \& Mitchell, 2008; Lusardi \& Mitchell, 2011), the questions are considered to be valid for measuring financial literacy. Besides, the questionnaire is reliable as it had a Cronbach Alpha value of 0.77. The value is therefore considered to be relatively high.

The questionnaire was targeted to individuals who worked in the South African banking sector. This included employees who worked in the front office, middle office and back office, and these employees were either client facing or non-client facing. Before collecting data, a pilot test was carried out on a sample of 10 individuals to ensure the survey reliability and to identify any potential errors. The data was finally collected over a period of a month from January to February 2017, and a total of 144 responses were collected. After the data clean-up process, the final sample was 120 individuals.

The sample consisted of $55 \%$ of females and $45 \%$ of males, whose average age ranged from 31 to 35 years. The race composition of the sample was Black African (76\%), White (10\%) and Others, including Asians, Indians and Coloreds (14\%). The sample consisted of educated individuals who had at least a matric certificate. Most individuals have an Honors degree (38\%). Furthermore, the sample included $45 \%$ single and $40 \%$ married individuals. The rest were either engaged or divorced. Finally, close distribution was observed in various office positions, and nearly half of the sample (48\%) worked in the banking sector for six to ten years. 


\subsection{Data analysis}

Both descriptive and inferential statistics were used. Descriptive statistics were used to understand the socio-demographic profile of the sample and the financial literacy scores of employees in the banking sector. Two-sample t-test and a simple Anova were used to investigate the financial literacy scores of the demographic groups in different categories. The results are discussed in the next section.

\section{RESULTS}

This section presents the study results. First, the descriptive statistics is laid out to provide an overview of the demographic composition of the sample and the respective financial literacy levels of each demographic group. The descriptive statistics are followed by the inferential statistics, which is necessary to test hypotheses.

\subsection{Sample demographics}

Table 1. Demographic data of the sample

\begin{tabular}{|c|c|c|c|c|}
\hline \multirow[b]{2}{*}{ Demographics } & \multirow[b]{2}{*}{$\begin{array}{l}\text { Frequency } \\
(n=120)\end{array}$} & \multicolumn{3}{|c|}{ Average score per racial group } \\
\hline & & $\begin{array}{c}\text { Basic } \\
\text { score } \\
\%\end{array}$ & $\begin{array}{c}\text { Advanced } \\
\text { score } \\
\%\end{array}$ & $\begin{array}{c}\text { Overall } \\
\text { score } \\
\%\end{array}$ \\
\hline \multicolumn{5}{|c|}{ Gender } \\
\hline Male & $54(45 \%)$ & 90 & 75.93 & 80.62 \\
\hline Female & 66 (55\%) & 79.70 & 67.12 & 71.31 \\
\hline \multicolumn{5}{|c|}{ Race } \\
\hline Black African & $91(76 \%)$ & 82.64 & 70.99 & 74.87 \\
\hline White & $12(10 \%)$ & 96.67 & 76.67 & 83.33 \\
\hline Asian & $1(0.8 \%)$ & 100 & 80 & 86.67 \\
\hline Colored & $5(4.2 \%)$ & 60 & 60 & 60 \\
\hline Indian & $11(9 \%)$ & 94.55 & 70 & 78.18 \\
\hline \multicolumn{5}{|c|}{ Age } \\
\hline $18-25$ years & $9(7.5 \%)$ & 82.22 & 70 & 74.07 \\
\hline $26-30$ years & $28(23.3 \%)$ & 85 & 68.93 & 74.29 \\
\hline $31-35$ years & $52(43.3 \%)$ & 84.23 & 71.15 & 75.51 \\
\hline $36-40$ years & $19(15.8 \%)$ & 85.26 & 72.11 & 76.49 \\
\hline $41-45$ years & $8(6.7 \%)$ & 80 & 75 & 76.67 \\
\hline $46-50$ years & $3(2.5 \%)$ & 93.33 & 76.67 & 82.22 \\
\hline $56-60$ years & 1 (0.9\%) & 80 & 70 & 73.33 \\
\hline \multicolumn{5}{|c|}{ Marital status } \\
\hline Single & $54(45 \%)$ & 86.67 & 72.22 & 77.04 \\
\hline $\begin{array}{l}\text { Living together/ } \\
\text { engaged }\end{array}$ & $11(9 \%)$ & 78.18 & 61.82 & 67.27 \\
\hline Married & $48(40 \%)$ & 82.50 & 71.87 & 75.42 \\
\hline $\begin{array}{l}\text { Divorced or } \\
\text { separated }\end{array}$ & $7(6 \%)$ & 88.57 & 71.43 & 77.14 \\
\hline
\end{tabular}

\begin{tabular}{|c|c|c|c|c|}
\hline \multirow[b]{2}{*}{ Demographics } & \multirow[b]{2}{*}{$\begin{array}{l}\text { Frequency } \\
(n=120)\end{array}$} & \multicolumn{3}{|c|}{ Average score per racial group } \\
\hline & & $\begin{array}{c}\text { Basic } \\
\text { score } \\
\%\end{array}$ & $\begin{array}{c}\text { Advanced } \\
\text { score } \\
\%\end{array}$ & $\begin{array}{c}\text { Overall } \\
\text { score } \\
\%\end{array}$ \\
\hline \multicolumn{5}{|c|}{ Education level } \\
\hline $\begin{array}{l}\text { Post-matric } \\
\text { certificate }\end{array}$ & $4(3 \%)$ & 60 & 57.50 & 58.33 \\
\hline $\begin{array}{l}\text { National } \\
\text { diploma }\end{array}$ & $6(5 \%)$ & 70 & 66.67 & 67.78 \\
\hline $\begin{array}{l}\text { Undergraduate } \\
\text { degree }\end{array}$ & $30(25 \%)$ & 73.33 & 63 & 66.44 \\
\hline $\begin{array}{l}\text { Postgraduate } \\
\text { diploma }\end{array}$ & $7(6 \%)$ & 88.57 & 74.29 & 79.05 \\
\hline Honors degree & $46(38 \%)$ & 90.87 & 75 & 80.29 \\
\hline $\begin{array}{l}\text { Master's } \\
\text { degree }\end{array}$ & $27(23 \%)$ & 91.11 & 75.56 & 80.74 \\
\hline \multicolumn{5}{|c|}{ Office position } \\
\hline Front office & $34(28 \%)$ & 86.47 & 77.06 & 80.20 \\
\hline Middle office & $41(34 \%)$ & 85.36 & 69.76 & 74.96 \\
\hline Back office & $38(32 \%)$ & 82.63 & 67.11 & 72.28 \\
\hline Other & $7(6 \%)$ & 77.14 & 71.08 & 73.33 \\
\hline \multicolumn{5}{|c|}{ Bank experience } \\
\hline $0-1$ years & $3(2.5 \%)$ & 80 & 53.33 & 62.22 \\
\hline $1-5$ years & $35(29.2 \%)$ & 83.43 & 69.43 & 74.10 \\
\hline $6-10$ years & $57(47.5 \%)$ & 83.51 & 72.46 & 76.14 \\
\hline $11-15$ years & $21(17.5 \%)$ & 87.62 & 71.43 & 76.83 \\
\hline $16-20$ years & $3(2.5 \%)$ & 93.33 & 76.67 & 82.22 \\
\hline $\begin{array}{l}\text { More than } 20 \\
\text { years }\end{array}$ & $1(0.8 \%)$ & 80 & 80 & 80 \\
\hline
\end{tabular}

Table 1 provides the descriptive analysis of the study in terms of gender, race, age, marital status, educational level, office position and bank experience. The descriptive analysis is based on a total sample size of 120 bank employees that were surveyed, and the results are discussed in the section below.

\subsection{Inferential statistics and data normality}

The parametric two-sample T-test and one-way Anova were used to determine the difference between means of financial literacy scores, where the categories were two or more. The two-sample T-test and one-way Anova are parametric tests with the assumption that the data follows a normal distribution and that the observations are independent (Pallant, 2010). Since the data set was large $(\mathrm{N}=120)$, the central limit theorem was used, which allowed the presumption of data normality.

\subsubsection{Two-sample T-test (independent T-Test)}

Table 2 displays the results of hypothesis 1: The average financial literacy scores of male employees 
in the banking sector are significantly different from those of their female counterparts. Based on this table, the hypothesis is accepted.

Table 2. Independent T-Test

\begin{tabular}{|c|c|c|}
\hline Demographic & $p$-value & Results \\
\hline Gender & 0.000 & $\begin{array}{l}\text { Hypothesis is accepted. } \\
\text { There is a significant difference } \\
\text { in the financial literacy scores of } \\
\text { males ( } M=80.62, S D=8.99) \text { and } \\
\text { females }(M=71.31, S D=14.84) \text {; } t \\
(118)=4.04, p<0.05) \text {. }\end{array}$ \\
\hline
\end{tabular}

\subsubsection{One-way ANOVA test}

Table 3. One-way ANOVA

\begin{tabular}{|c|c|c|}
\hline Demographic & p-value & Results \\
\hline Age & 0.943 & $\begin{array}{l}\text { Hypothesis is rejected. } \\
\text { There is no significant difference } \\
\text { in the average financial literacy } \\
\text { scores of the age categories at } \\
\text { the } P<0.05 \text { level for all the age } \\
\text { categories }[F(5,113)=0.24, p= \\
0.943\end{array}$ \\
\hline Race & 0.008 & $\begin{array}{l}\text { Hypothesis is accepted. } \\
\text { There is a significant difference } \\
\text { in the average financial literacy } \\
\text { scores of the racial groups at the } \\
P<0.05 \text { level for the five racial } \\
\text { groups }[F(3,115)=4.14, p=0.08\end{array}$ \\
\hline Marital status & 0.171 & $\begin{array}{l}\text { Hypothesis is rejected. } \\
\text { There is no significant difference } \\
\text { in the average financial literacy } \\
\text { scores of the marital status } \\
\text { groups at the } P<0.05 \text { level for } \\
\text { the four marital groups }[F(3,116) \\
=1.70, p=0.171\end{array}$ \\
\hline Education level & 0.000 & $\begin{array}{l}\text { Hypothesis is accepted. } \\
\text { There is a significant difference } \\
\text { in the average financial literacy } \\
\text { scores of the education groups } \\
\text { at the } P<0.05 \text { level for the six } \\
\text { educational groups }[F(5,114)= \\
8.77, p=0.000\end{array}$ \\
\hline Office position & 0.081 & $\begin{array}{l}\text { Hypothesis is rejected. } \\
\text { There is no significant difference } \\
\text { in the financial literacy scores of } \\
\text { the office position groups at the } \\
P<0.05 \text { level for the four office } \\
\text { positions }[F(3,116)=2.30, p= \\
0.81\end{array}$ \\
\hline $\begin{array}{l}\text { Banking } \\
\text { experience }\end{array}$ & 0.355 & $\begin{array}{l}\text { Hypothesis is rejected. } \\
\text { There is no significant difference } \\
\text { in the financial literacy scores of } \\
\text { the various banking experiences } \\
\text { at the } P<0.05 \text { level for the five } \\
\text { groups }[F(4,114)=1.11, p=0.355\end{array}$ \\
\hline
\end{tabular}

Note: $* *$ significant at the 0.05 level.
A one-way ANOVA test was conducted to compare financial literacy scores between demographic variables, namely, age, race, marital status, education level, office position and banking experience. Only hypotheses 3 and 5 are accepted, while 2, 4, 6 and 7 are rejected. These results are discussed in detail in the section below.

\section{DISCUSSION}

\subsection{Descriptive analysis and overall financial literacy of bank employees}

As Table 1 shows, women have lower financial literacy scores compared to men. This is the case in both basic and advanced financial literacy questions. Their overall average score is $71 \%$ in contrast to an average score of $81 \%$ for the male counterparts. This result agrees with that of Almenberg and Säve-Söderbergh (2011), Shambare and Rugimbana (2012) and Boisclair, Lusardi, and Michaud (2017). The authors also found that men were more financially literate compared to women.

Coloreds scored the lowest in overall financial literacy in comparison to all the other population groups, namely, Asians, Black Africans, Indians and Whites. After the Asians who have the highest overall financial literacy score of $87 \%$, Whites have the second highest financial literacy scores in both advanced and basic financial literacy questions, resulting in the overall financial literacy score of $83 \%$. Black Africans have an overall score of $75 \%$, whilst Indians and Coloreds have $78 \%$ and $60 \%$, respectively. Therefore, the findings are different from those of Roberts, Struwig, and Gordon (2012) and Matemane (2018) who found Black Africans the most financially illiterate.

It was found that people aged 46 to 50 had the highest overall financial literacy score. The overall financial literacy score of those aged 18 to 25 and 26 to 30 is indifferent, since both groups have an average of $74 \%$. This average increases slightly among people aged 31 to 40 , since they reached $76 \%$. Then, the financial literacy score increases among people above 41 years, who achieved $77 \%$ and above. The emerging pattern of the financial literacy scores based on age, therefore, mirrors the 
finding of the study conducted by Almenberg and Säve-Söderbergh (2011) who found that financial literacy is lower for the younger population.

Table 1 also indicates that bank employees who are not in a "live-in" relationship had higher financial literacy scores. This is demonstrated by the fact that both the single and divorced/separated banking employees achieved a financial literacy score of $77 \%$. On the other hand, living together/engaged and married individuals have scores of $67 \%$ and $75 \%$, respectively. As expected, when people advance in education levels, their overall financial literacy scores also advance. Individuals with a postgraduate qualification exhibit higher financial literacy scores, as they scored $80 \%$ in comparison to those with an undergraduate degree or lower qualification who scored $60 \%$. This confirms the findings of Lusardi and Mitchell (2011) and Boisclair, Lusardi, and Michaud (2017), who found that the education level is an important determinant of financial literacy.

In addition, people who work in the front office have a higher financial literacy score $(80 \%)$ than those working in the middle (75\%) or back offices (72\%). Besides, the descriptive statistics indicate that the more an individual worked in the banking sector, the higher the financial literacy score. Those who have experience in the banking sector from 16 to 20 years have the highest financial literacy score $-82 \%$, and those who have less than a year of experience gained only $62 \%$.

Bank employees achieved an average score of $84 \%$ in the basic financial literacy questions. In this category, the sample found the numeracy question to be the easiest and the money illusion concept to be the most difficult. The advanced financial literacy questions assessed knowledge of investments and investment choices. The sample's average score for this category is $71 \%$. This indicates that the sample is knowledgeable in the area of investments and investment choices. Overall, the sample had an average financial literacy score of $76 \%$ for both categories.

According to Chen and Volpe (2002), individuals who score between 0 to $39 \%$ have low levels of financial literacy, whilst those who score 40 to $59 \%$ have medium levels of financial literacy, and those with 60 to $100 \%$ have financial literacy levels that are significantly high. Therefore, bank employees are highly literate in advanced and basic financial literacy questions resulting in the overall high level of financial literacy.

\subsection{Two sample t-test and simple Anova}

According to Table 2, the two-sample T-test was conducted to compare overall financial literacy scores between males and females. There was a significant difference in the scores of males $(\mathrm{M}=$ 80.62, $\mathrm{SD}=8.99)$ and females $(\mathrm{M}=71.31, \mathrm{SD}=$ $14.84) ; \mathrm{t}(118)=4.04, \mathrm{p}<0.05)$. The results suggest that males are more financially literate compared to their female counterparts. Specifically, the results suggest that men have higher scores in financial literacy when both basic and advance financial literacy questions are aggregated.

On the other hand, one-way Anova test only found statistically significant differences within race and education level groups, thus accepting the hypotheses as exhibited in Table 3. For the remainder of the demographic groups, the null hypotheses were rejected, as there were no significant differences within the various groups. In conclusion, the financial literacy differences between males and females are statistically significant, with the males being more financially literate. Furthermore, financial literacy score was found to be significantly different between races and education levels.

\subsection{Post hoc comparisons}

With regard to race, the post hoc comparisons using Tukey HSD test indicated that the average scores for Coloreds $(M=60, S D=19.44)$ are significantly different from those of Indians $(\mathrm{M}=78.18$, $\mathrm{SD}=16.08)$ and Whites $(\mathrm{M}=83.33, \mathrm{SD}=5.32)$. However, the mean score for Coloreds $(M=60$, $\mathrm{SD}=19.44)$ is not significantly different from that of the Black Africans $(\mathrm{M}=74.87, \mathrm{SD}=12.73)$.

On the other hand, post hoc comparisons using Tukey HSD test also indicated that the mean score for the participants possessing post-matric Certificate $(M=58.33, S D=19.91)$ is significantly different from those who possess Honors ( $\mathrm{M}=$ $80.29, \mathrm{SD}=10.23)$ and Masters $(\mathrm{M}=80.74, \mathrm{SD}=$ 
8.33) degrees. However, the mean score of those who possess post-matric Certificate $(M=58.33$, $\mathrm{SD}=19.91)$ is not significantly different from those who possess National Diploma $(\mathrm{M}=67.78$, $\mathrm{SD}=11.48)$, Postgraduate Diploma $(M=79.05$, $\mathrm{SD}=8.10)$ or undergraduate Degree $(\mathrm{M}=66.44$, $\mathrm{SD}=15.01)$

\subsection{Effect size}

In the three demographic variables, where significant differences were found, the effect sizes were calculated as follows:

- For gender (independent t-test) $=4.232 /$ $[4.232+(54+66-2)]=0.035$
- For racial groups (one-way Anova) = $2,051.562 / 21,044.258=0.097$

- For education levels (one-way Anova) = $5,881.695 / 21,170.000=0.28$

According to Cohen (1988), effect size of 0.01 indicates low effect, whilst 0.06 and 0.14 indicate moderate and large effects, respectively. Therefore, the significant differences obtained for gender demographic variable have a low to medium effect. On the other hand, the significant differences obtained for the race demographic variable have a medium to large effect, whilst the effect size of the education level demographic variable is very large.

\section{CONCLUSION}

The main objective of this study was to explore the financial literacy levels of employees in the banking sector in South Africa. Using Chen and Volpe's (2002) classification of financial literacy scores, the study finds that the employees have high levels of financial literacy $-76 \%$. The employees have a higher mean for the basic financial literacy questions compared to the advanced financial literacy questions. The financial literacy levels of employees in the banking sector did not depend on their number of years of work in the banking sector. There was also no significant difference in the overall financial literacy levels of employees who work in the front, middle or back offices.

The study further assessed whether certain demographic factors had an influence on the financial literacy levels of employees. The study focused on gender, age, race, education level and marital status. Of these demographic factors, only gender, race and education level were found to have an influence on financial literacy. Men were found to have higher financial literacy levels compared to their female counterparts. The Asian population was found to have the highest financial literacy scores in comparison to other races, followed by Whites. In addition, the higher the education level, the higher the financial literacy level.

This study contributes to existing literature on financial literacy, as limited studies have explored the financial literacy levels of bank employees in the context of South Africa and a developing country. The results also inform the government and various institutions about how well employees in the banking sector are equipped with financial literacy skills needed to advise their clients and manage their savings and investments. It is further reported on whichbanking employee groups should focus on giving more financial education.

\section{RECOMMENDATIONS}

Like any other scientific investigations, this study has some limitations. Firstly, the sample was not randomly selected, but was based on purposeful, convenient and snowballing sampling techniques. Secondly, the study is limited to a single jurisdiction, namely South Africa. Therefore, it is recommended that future studies use a random sample and cover several jurisdictions, such as developed and other developing economies. Although South African financial systems are considered much more devel- 
oped and sophisticated, they probably do not mirror the systems of other emerging markets in Africa. Furthermore, conditions of a developing country such as South Africa would differ from conditions of developed economies. Therefore, a comparative study can also add to the authors' understanding of commonalities and differences between developed and developing economies in terms of financial literacy determinants. In addition, the study only explored the nature of the relationship between financial literacy and several demographic factors in the banking sector. Thus, a study of financial literacy of employees in different sectors of the economy can also be useful for understanding financial literacy of employees in different sectors.

\section{AUTHOR CONTRIBUTIONS}

Conceptualization: Alicia Lethepa, Reon Matemane.

Data curation: Alicia Lethepa.

Formal analysis: Alicia Lethepa.

Funding acquisition: Reon Matemane.

Investigation: Alicia Lethepa, Nyasha Dhlembeu.

Methodology: Alicia Lethepa, Reon Matemane, Nyasha Dhlembeu.

Project administration: Reon Matemane, Nyasha Dhlembeu.

Resources: Alicia Lethepa, Reon Matemane.

Software: Alicia Lethepa.

Supervision: Reon Matemane.

Validation: Alicia Lethepa, Reon Matemane, Nyasha Dhlembeu.

Visualization: Alicia Lethepa, Nyasha Dhlembeu.

Writing - original draft: Alicia Lethepa.

Writing - reviewing \& editing: Reon Matemane, Nyasha Dhlembeu.

\section{REFERENCES}

1. Almenberg, J., \& Säve-Söderbergh, J. (2011). Financial literacy and retirement planning in Sweden. Journal of Pension Economics and Finance, 10(04), 585-598. https://doi.org/10.1017/ S1474747211000497

2. Atkinson, A., \& Messy, F. (2012). Measuring financial literacy: results of the OECD/International Network on Financial Education (INFE) pilot study (OECD Working Papers on Finance, Insurance and Private Pensions, No. 15). Paris: OECD Publishing. https://doi. org/10.1787/5k9csfs90fr4-en

3. Babiarz, P., \& Robb, C. A. (2014). Financial literacy and emergency saving. Journal of Family and Economic Issues, 35(1), 40-50. https://doi.org/10.1007/s10834013-9369-9

4. Bashir, T., Arshad, A., Nazir, A., \& Afzal, N. (2013). Financial literacy and influence of psychosocial factors. European Scientific Journal,
9(28), 384-404. Retrieved from https://eujournal.org/index.php/ esj/article/view/1905/1847

5. Boisclair, D., Lusardi, A., \& Michaud, P. C. (2017). Financial literacy and retirement planning in Canada. Journal of Pension Economics \& Finance, 16(3), 277-296. Retrieved from https://www.cirano.qc.ca/files/ publications/2014s-35.pdf

6. Botha, M. (2014). A comparative analysis of the financial literacy of final year diploma students in different fields of study at the University of Johannesburg (Thesis). Johannesburg: University of Johannesburg. Retrieved from https://ujcontent.uj.ac.za/vital/access/services/Download/uj:7955/ CONTENT1?view=true

7. Brown, M., \& Graf, R. (2013) Financial literacy \& retirement planning in Switzerland. Numeracy, 6(2), 1-21. http://dx.doi. org/10.5038/1936-4660.6.2.6
8. Bucher-Koenen, T., \& Lusardi, A. (2011). Financial literacy and retirement planning in Germany. Journal of Pension Economics and Finance, 10(4), 565-584. Retrieved from https://papers.ssrn.com/sol3/ papers.cfm?abstract_id=1861851

9. Chen, H., \& Volpe, R. P. (2002). Gender differences in personal financial literacy among college students. Financial Services Review, 11(3), 289-307. Retrieved from https://www.questia.com/library/ journal/1P3-977861591/genderdifferences-in-personal-financialliteracy

10. Chetty, K. (2011). Bank disintermediation - South Africa (Unpublished Master's Dissertation). Johannesburg: University of the Witwatersrand. Retrieved from http://wiredspace.wits.ac.za/bitstream/ handle/10539/11577/Bank\%20 Disintermediation\%20South\%20 Africa\%20-\%20Kuben\%20 
Chetty\%20-\%20updated. pdf? sequence $=1$ \&isAllowed $=y$

11. Cohen, J. (1988). Statistical power analysis for the behavioral sciences ( $2^{\text {nd }}$ ed.). Hillsdale, N. J.: Lawrance Erlbaum. Retrieved from http:// www.utstat.toronto.edu/ brunner/ oldclass/378f16/readings/CohenPower.pdf

12. De Bassa Scheresberg, C. (2013). Financial literacy and financial behavior among young adults: Evidence and implications. Numeracy, 6(2), 5. http://dx.doi. org/10.5038/1936-4660.6.2.5

13. Dudchyk, O., Matvijchuk, I., Kovinia, M., Salnykova, T., \& Tubolets, I. (2019). Financial literacy in Ukraine: from micro to macro level. Investment Management and Financial Innovations, 16(4), 240-253. http://dx.doi.org/10.21511/ imfi.16(4).2019.21

14. Erasmus, C. (2014). An empirical study of bank efficiency in South Africa using the standard and alternative approaches to data envelopment analysis (DEA). Journal of Economics and Behavioral Studies, 6(4), 310-317. https://doi.org/10.22610/jebs. v6i4.494

15. Fatoki, O., \& Oni, O. (2014). Financial literacy studies in South Africa: current literature and research opportunities. Mediterranean Journal of Social Sciences, 5(20), 409-414. http:// dx.doi.org/10.5901/mjss.2014. v5n20p409

16. Fonseca, R., Mullen, K., Zamarro, G., \& Zissimopoulus, J. (2012). What explains the gender gap in financial literacy? The role of household decision making. Journal of Consumer Affairs, 46(1), 90-106. https://doi.org/10.1111/ j.1745-6606.2011.01221.x

17. Hung, A., Parker, A. M., \& Yoong, J. (2009). Defining and measuring financial literacy (RAND Working Paper WR-708). Retrieved from https://www.rand.org/content/ dam/rand/pubs/working_papers/2009/RAND_WR708.pdf

18. Hussain, I., \& Sajjad, S. (2016). Significance of Financial Literacy and Its Implications: A Discussion. Journal of Business Strategies, 10(2), 141. Retrieved from https://www.thefreelibrary.com/ SIGNIFICANCE+OF+FINANCIA L+LITERACY+AND+ITS+IMPLI CATIONS\%3A+A+DISCUSSION -a0484978021

19. Huston, S. J. (2010). Measuring financial literacy. Journal of Consumer Affairs, 44(2), 296-316. https://doi.org/10.1111/j.17456606.2010.01170.x

20. Jana, D., Sinha, A., \& Gupta, A. (2019). Determinants of Financial Literacy and Use of Financial Services: An Empirical Study amongst the Unorganized Sector Workers in Indian Scenario. Iranian Journal of Management Studies, 12(4), 657675. https://dx.doi.org/10.22059/ ijms.2019.268945.673392

21. Klapper, L., \& Lusardi, A. (2019). Financial literacy and financial resilience: Evidence from around the world. Financial Management. https://doi.org/10.1111/ fima. 12283

22. Lachance, M.-E. (2014). Financial literacy and neighborhood effects. Journal of Consumer Affairs, 48(2), 251-273. https://doi.org/10.1111/ joca.12024

23. Louw, J., Fouché, J., \& Oberholzer, M. (2013). Financial literacy needs of South African third-year university students. International Business \& Economics Research Journal (IBER), 12(4), 439-450. Retrieved from https://clutejournals.com/index.php/IBER/article/ view/7742

24. Lusardi, A., \& Mitchell, O. S. (2008). Planning and financial literacy: How do women fare? American Economic Review, 98(2), 413-417. https://doi.org/10.1257/ aer.98.2.413

25. Lusardi, A., \& Mitchell, O. S. (2009). Financial literacy: evidence and implications for financial education. Retrieved from https:// www.tiaainstitute.org/sites/default/files/presentations/2017-02/ ti_financialliteracy0509a.pdf

26. Lusardi, A., \& Mitchell, O. S. (2011). Financial literacy around the world: an overview. Journal of Pension Economics \& Finance, 10(4), 497-508. https://doi. org/10.1017/S1474747211000448

27. Lusardi, A., \& Mitchell, O. S. (2014). The economic importance of financial literacy: Theory and evidence. Journal of Economic Literature, 52(1), 5-44. http:// dx.doi.org/10.1257/jel.52.1.5

28. Matemane, M. R. (2018). Saving for tomorrow: does the level of financial literacy in the South African working class matter? Southern African Business Review, 22(1), 1-21. https://doi. org/10.25159/1998-8125/4443

29. Mundy, S., \& Masok, C. (2011). Towards an effective framework for financial literacy and financial consumer protection in Uganda (Bank of Uganda Paper). Retrieved from https:// www.findevgateway.org/sites/ default/files/publications/files/ mfg-en-paper-towards-aneffective-framework-for-financialliteracy-and-financial-consumerprotection-in-uganda-mar-2011. pdf

30. Murendo, C., \& Mutsonziwa, K. (2017). Financial literacy and savings decisions by adult financial consumers in Zimbabwe. International journal of Consumer Studies, 41(1), 95-103. https://doi. org/10.1111/ijcs.12318

31. Ngek, N. B. (2016). Performance implications of financial capital availability on the financial literacy-performance nexus in South Africa. Investment Management and Financial Innovations, 13(2), 354-362. http:// dx.doi.org/10.21511/imfi.13(22). 2016.10

32. Nguyen, T. A. N., \& Rozsa, Z . (2019). Financial Literacy and Financial Advice Seeking for Retirement Investment Choice. Journal of Competitiveness, 11(1), 70-83. https://doi.org/10.7441/ joc.2019.01.05

33. Onyango, O. S. (2014). Effect of financial literacy on management of personal finances among employees of commercial banks in Kenya (Unpublished master's dissertation). Nairobi: University 
of Nairobi. Retrieved from http:// erepository.uonbi.ac.ke/handle/11295/75315

34. OECD International Network on Financial Education (OECD INFE). (2011). Measuring financial literacy: Questionnaire and guidance notes for conducting an internationally comparable survey of financial literacy. Paris: OECD. OECD International Network on Financial Education (INFE). Retrieved from http:// www.oecd.org/finance/financialeducation/49319977.pdf

35. Oseifuah, E. K., \& Gyekye, A. B. (2014). Analysis of the level of financial literacy among South African undergraduate students. Journal of Economics and Behavioral Studies, 6(3), 242-250. Retrieved from https:// ideas.repec.org/a/rnd/arjebs/ v6y2014i3p242-250.html

36. Pallant, J. (2010). SPSS survival manual: a step by step guide to data analysis using SPSS. Maidenhead, Open University Press/McGraw-Hill.

37. Refera, M. K., Dhaliwal, N. K., \& Kaur, J. (2016). Financial literacy for developing countries in Africa: A review of concept, significance and research opportunities. Journal of African Studies and Development, 8(1), 1-12. https:// doi.org/10.5897/JASD2015.0331

38. Roberts, B., Struwig, J., \& Gordon, S. (2014). Financial literacy in South Africa: results from the 2013 South African social attitudes survey round. Pretoria: Financial Services Board. Retrieved from https://www.alexanderforbes. co.za/download/afo/benefitsbarometer/Article\%20Documents/ Financial-Literacy-Report.pdf

39. Sallie, N. (2015). The impact of socialisation factors on financial literacy and financial security amongst employees in the financial services industry (MBA Thesis). Pretoria: Gordon Institute of Business Science, University of Pretoria. Retrieved from http://hdl. handle.net/2263/52308

40. Seth, T. (2014). Essay on the role of banks in economic development. Retrieved from http://www. economicsdiscussion.net/essays/ essay-on-the-role-of-banks-ineconomic-development/1875

41. Shambare, R., \& Rugimbana, R. (2012). Financial literacy among the educated: an exploratory study of selected university students in South Africa. Thunderbird International Business Review, 54(4), 581-590. Retrieved from https://www.academia. edu/10794246/Financial_literacy_ among_the_educated_An_exploratory_study_of_selected_university_students_in_South_Africa

42. Snyman, J. (2014). The effect of financial literacy on financial outcomes in South Africa (Master's Thesis). Stellenbosch: Stellenbosch University. Retrieved from http:// citeseerx.ist.psu.edu/viewdoc/dow nload?doi $=10.1 \cdot 1 \cdot 850.5665 \& \mathrm{rep}=\mathrm{r}$ ep $1 \&$ type $=p d f$

43. Statistics South Africa (Stats SA). (2019). Gross domestic product, $4^{\text {th }}$ quarter 2018. Retrieved from http://www.statssa.gov.za/publications/P0441/GDP_2018_Q4_Media_presentation.pdf

44. Taylor, S., \& Wagland, S. (2011). Financial literacy: a review of government policy and initiatives. Australasian Accounting, Business and Finance Journal, 5(2), 101-125. Retrieved from https://ro.uow.edu. au/aabfj/vol5/iss2/7/

45. Van Rooij, M., Lusardi, A., \& Alessie, R. (2011a). Financial literacy and retirement planning in the Netherlands. Journal of economic psychology, 32(4), 593-608. Retrieved from https:// www.dnb.nl/en/binaries/231\%20 Financial\%20Literacy\%20and\%20 Retirement\%20Planning\%20 in $\% 20$ the $\% 20$ Netherlands_tcm 47 225547.pdf

46. Van Rooij, M. Lusardi, A., \& Alessie, R. (2011b). Financial literacy and stock market participation. Journal of Financial Economics, 101(2), 449-472. Retrieved from https://www. dartmouth.edu/ alusardi/Papers/ Literacy_StockMarket.pdf

47. Xu, L., \& Zia, B. (2012). Financial Literacy around the world (Policy Research Working Paper WPS/6107). Retrieved from http:// documents.worldbank.org/curated/en/264001468340889422/ Financial-literacy-around-theworld-an-overview-of-the-evidence-with-practical-suggestionsfor-the-way-forward

48. Xue, R., Gepp, A., O’Neill, T. J., Stern, S., \& Vanstone, B. J. (2019). Financial literacy amongst elderly Australians. Accounting \& Finance, 59, 887-918. https://doi. org/10.1111/acfi.12362 